\title{
EFFECT OF SYNTHESIS TEMPERATURE ON MORPHOLOGY AND STRUCTURAL CHARACTERISTICS OF HYDROXYAPATITE WHISKERS
}

\author{
HONGQUAN ZHANG \\ State Key Laboratory of Silicate Materials for Architecture (Wuhan University of Technology), Wuhan 430070, China \\ School of Materials Science and Engineering, Wuhan University of Technology, Wuhan 430070, China \\ E-mail: zhhquan@whut.edu.cn
}

Submitted December 14, 2017; accepted February 6, 2018

\begin{abstract}
Keywords: Hydroxyapatite whiskers, Starting pH, Calcium/phosphate ratio, Synthesis temperature, Constitution and morphology
Synthesis temperature shows important effects on the hydrolysis rate of acetamide (AA) additive and the driving forces for the formation of nuclei and the grow th of hydroxyapatite (HA) crystals from aqueous solution. Variation in the temperature in the present work affected neither the constitution \& crystallinity of the products nor the crystal growth habit along the c-axis. However, the morphology of products greatly depended on the synthesis temperature and was correlated with the starting $\mathrm{pH}$ of the solution. Higher initial $\mathrm{pH}$ only provided a basic reference for quickly obtaining supersaturation for the formation of HA nuclei. Lath-or branch-like HA often appeared in the whiskers at high initial pH, being independent of the synthesis temperatures. Neither high nor low temperatures were beneficial to the preparation of long HA with high aspect ratio. 180 $200^{\circ} \mathrm{C}$ seemed to be an appropriate synthesis temperature to prepare long HA whiskers from a solution with Ca/P 1.67 and starting $\mathrm{pH}$ 3. The Ca/P ratio of products increased with the temperature, and the whiskers obtained at low temperature had high calcium deficiency.
\end{abstract}

\section{INTRODUCTION}

Hydroxyapatite $\left(\mathrm{Ca}_{10}\left(\mathrm{PO}_{4}\right)_{6}(\mathrm{OH})_{2}\right.$, HA) is one of the most bioactive and biocompatible materials, and has been accepted and used widely and successfully to repair bone and tooth defects [1]. However, inferior mechanical properties and reliability make HA ceramics unsuitable for load-bearing situations. Moreover, composites filled with HA particles have been found to fall short in terms of mechanical strength and durability $[2,3]$. To satisfy the physico-chemical demands for clinical applications, reinforcement of HA ceramics and composites have acquired a great deal of importance in past decades. Although reinforcement by whiskers or fibers has been considered as an effective way of improving the mechanical properties [4], most available ceramic, metal and polymer fibrous materials are at least bio-inert, easily provoking a fibrous tissue capsule of a variety of thicknesses when implanted in the body, decreasing the biocompatibility and bioactivity [5-8]. With this view, HA whiskers or fibres appear to be one of the most promising candidates to reinforce the mechanical and biological properties of biocomposite materials. So far, HA whiskers or fibrous HA have been prepared by a variety of methods, such as growth in gel [9], solidstate reaction [10], wet chemical precipitation [11, 12], dissolution-precipitation [13], hydrothermal synthesis $[14,15]$, molten salt synthesis [16] and electrospun [17].
Among these methods, wet chemical synthesis has been considered as a major route widely-used due to low cost and simplicity. However, whiskers with controlled morphology and composition are difficult to prepare due to the sensitivity to the preparation conditions $[18,19]$, and the whiskers prepared by most method mentioned above are generally $\mathrm{Ca}$-deficient, with low aspect ratio $[11,12]$. Therefore, preparation of long HA whiskers with high aspect ratio is of potential significance for the development of candidate biomaterials for large stressbearing dental restorations and hard tissue replacement.

Nucleation and crystal growth of whisker-like and fibrous HA from aqueous solution greatly depend on the properties of starting solution and can be controlled by a slow release of $\mathrm{Ca}$ ions or by the control of reaction $\mathrm{pH}$ value $[11,20-22]$. However, the products obtained usually have a large variation in length and aspect ratio, depending on the synthesis methods, concentration of each reactant and temperature. In the case of hydrothermal synthesis, although aqueous solutions containing $\mathrm{Ca}$ (or $\mathrm{Ca}$-chelae) and $\mathrm{PO}_{4}$ could yield whisker-like $\mathrm{HA}$ at $120-200^{\circ} \mathrm{C}$ in the presence of additives, for examples of urea, $\mathrm{KOH}, \mathrm{K}_{3} \mathrm{PO}_{4}$ and EDTA $[15,20,23-25]$, the outcome was mainly fibrous HA, with low aspect ratio and short length; the nucleation and growth of HA crystals were found to be affected by the synthesis temperature. Unfortunately, despite much effort to improve the quality of HA whiskers, no more 
relevant work concerning the effect of the synthesis temperature have been reported. To prepare long and uniform HA whiskers with high aspect ratio, high purity and good crystallinity, acetamide (AA) was introduced as hydrothermal homogeneous precipitation agent to control the nucleation and growth of HA whiskers at low degree of supersaturation in our previous works [26, 27]. The morphology and structural characteristics of the whiskers were strongly affected by the preparation conditions. The purpose here is to elucidate the effect of synthesis temperature on the morphology and growth characteristics of HA whiskers using such additive.

\section{EXPERIMENTAL}

\section{Preparation}

Aqueous solutions containing $\mathrm{Ca}$ and $\mathrm{PO}_{4}$ were prepared by dissolving analytical grade reagents $\mathrm{Ca}\left(\mathrm{NO}_{3}\right)_{2} \cdot 4 \mathrm{H}_{2} \mathrm{O}$ and $\left(\mathrm{NH}_{4}\right)_{2} \mathrm{HPO}_{4}$ based on $0.05 \mathrm{~mol} \cdot \mathrm{l}^{-1}$ $\mathrm{Ca}$ and $1 \mathrm{~mol} \cdot \mathrm{l}^{-1}$ acetamide (99\%, Alfa Aesar, Heysham, Lancashire, England). Aqueous calcium and phosphate solutions with a fixed $\mathrm{Ca} / \mathrm{P}$ ratio of 1.67 were used in the first group. The starting $\mathrm{pH}$ of each solution was adjusted to 2,3 , or 4 using $0.1 \mathrm{~mol} \cdot \mathrm{l}^{-1} \mathrm{HNO}_{3}$ or $1: 1 \mathrm{NH}_{4} \mathrm{OH}$. After processing at $140,160,180,200$ and $220^{\circ} \mathrm{C}$ for $10 \mathrm{~h}$, respectively, as reported previously [27], the mixture was cooled naturally over $12 \mathrm{~h}$ to the ambient temperature. The product was then filtered and washed quickly with deionized water four times, and dried in air at $80^{\circ} \mathrm{C}$.

\section{Characterization}

The constitution and crystallinity of the product was characterized using X-ray diffraction (XRD) (X'Pert Pro, PANalytical BV, Almelo, The Netherlands) and Fourier-transform infrared spectroscopy (FTIR) (FTS-165, Bio-Rad Inc., Hercules, CA, USA). Morphology and microstructure were observed using scanning electron microscopy (SEM) (Model XL30CP, Philips Electron Optics, Eindhoven, The Netherlands). Transmission electron microscopy (TEM) observation, selected-area electron diffraction (SAED) patterns and high-resolution TEM (HRTEM) images of HA whiskers were performed on a Tecnai G2 20 S-TEM (FEI, Philips, Hillsboro OR, USA) to identify the growth direction of whiskers. XRD pattern processing software (MDI Jade 5, Materials Data Inc., Livermore, Livermore, California, USA) was used for phase identification and lattice parameter calculation. Image processing software (QWin, Leica Microsystems Imaging Solutions Ltd., Cambridge, UK) was used to determine the aspect ratio of the whiskers and $d$-spacings. The degree of crystallinity (Xc) of the HA whiskers was evaluated by the following equation according to the examined XRD diffractograms [28]:

$$
\mathrm{Xc}=1-\left(V_{112 / 300} / I_{300}\right)
$$

where $V_{112 / 300}$ is the intensity of the hollow between (112) and (300) peaks and $I_{300}$ is the intensity of the (300) peak. In addition, the $\mathrm{Ca} / \mathrm{P}$ ratio was determined by energy dispersive X-ray spectroscopy (EDX) using a field emission-scanning electron microscope (FE-SEM) (LEO 1530, Oxford Instruments, Abingdon, UK). The EDX results were believed to be accurate to about $5 \%$. The $\mathrm{pH}$ of the solution was measured with a combination electrode at room temperature $\left(25 \pm 2^{\circ} \mathrm{C}\right)$. After processing, the $\mathrm{pH}$ of the filtrate was measured as representing the final $\mathrm{pH}$ of the synthesis solution.

\section{RESULTS}

\section{Constitution and structural characteristics}

Figures 1 and 2 show the XRD patterns and FTIR spectra of samples of the HA prepared at various temperatures. The products showed similar XRD patterns and FTIR spectra, as reported in previous studies [26, 27]. All XRD peaks matched well those of the reference diffraction pattern (JCPDS PDF 9-432) for synthetic HA, and the products were identified by XRD as Ca-deficient $\mathrm{HA}$, with a $\mathrm{Ca} / \mathrm{P}$ of $1.59-1.62$ (Table 1). No other phase than HA was detected. The lattice parameters calculated from the XRD patterns varied: for $a$ from 9.430 to $9.435 \AA$, and for $c$ from 6.8817 to $6.9013 \AA$, coinciding well with those calculated from the reference (JCPDS PDF 9-432). Both $a$ and $c$ values were slightly greater than for stoichiometric HA. Increasing the synthesis tem-perature affected neither the lattice parameters nor the crystallinity, but giving rise to an increase in the final $\mathrm{Ca} / \mathrm{P}$ ratio of the product. For specimens of the products prepared at $160-220^{\circ} \mathrm{C}$, the XRD intensity

Table 1. Summary of Synthesis parameter and characteristics of the products. All at $180^{\circ} \mathrm{C}$, for $10 \mathrm{~h}$; starting pH 3 and Ca/P 1.67 , and $[\mathrm{AA}]=1 \mathrm{~mol} \cdot \mathrm{l}^{-1}$.

\begin{tabular}{cccccc}
\hline $\begin{array}{c}\text { Temperature } \\
\left({ }^{\circ} \mathrm{C}\right)\end{array}$ & $\begin{array}{c}\text { Final } \\
\mathrm{pH}\end{array}$ & $\begin{array}{c}\mathrm{Ca} / \text { P ratio } \\
\text { of product }\end{array}$ & $\begin{array}{c}\text { Crystallinity } \\
(\%)\end{array}$ & Lattice parameter \\
\hline 140 & 5.09 & 1.59 & 96.87 & $\mathrm{a}(\AA)\left(\mathrm{a}_{\text {obs. }} \pm\right.$ S.D. $)$ & $\mathrm{c}(\AA)\left(\mathrm{c}_{\text {obs. }} \pm \mathrm{S} . \mathrm{D}.\right)$ \\
160 & 5.29 & 1.61 & 96.44 & $9.433 \pm 0.003$ & $6.895 \pm 0.004$ \\
180 & 5.67 & 1.62 & 96.09 & $9.435 \pm 0.003$ & $6.901 \pm 0.006$ \\
200 & 5.55 & 1.61 & 95.96 & $9.434 \pm 0.004$ & $6.896 \pm 0.002$ \\
220 & 5.53 & 1.61 & 96.17 & $9.434 \pm 0.002$ & $6.898 \pm 0.004$ \\
\hline
\end{tabular}




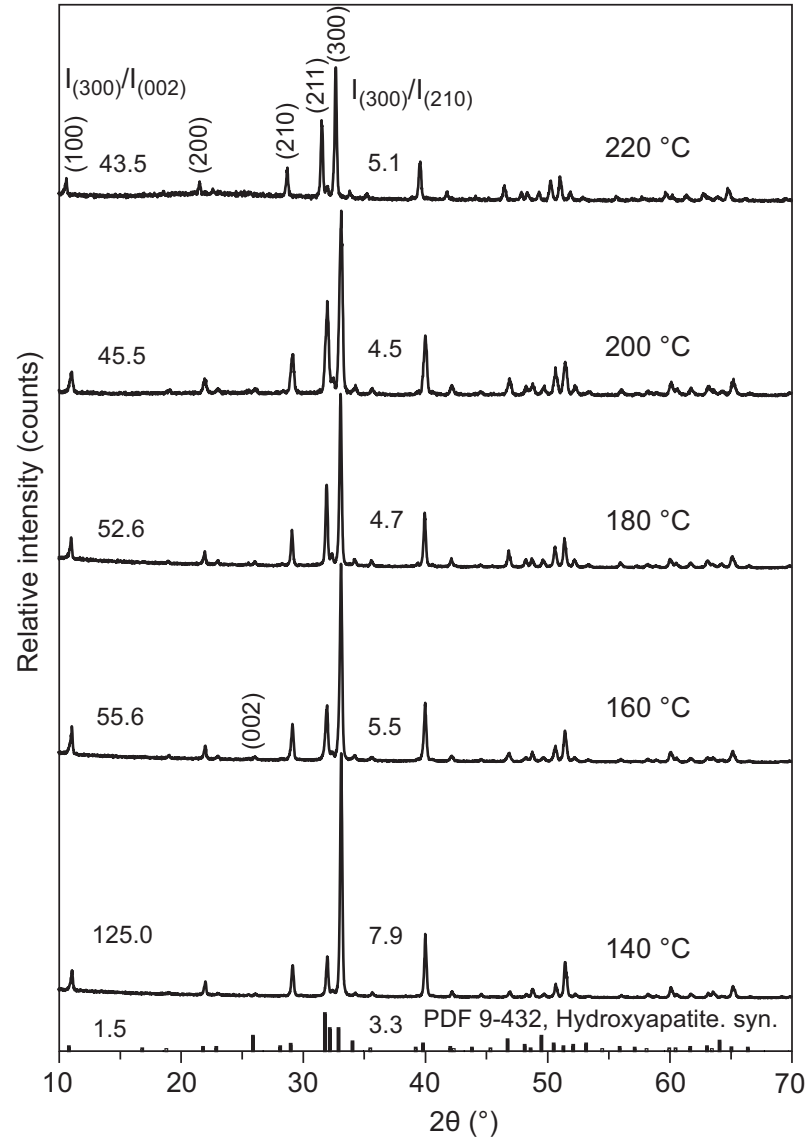

Figure 1. XRD patterns of HA prepared at various temperatures using solutions with a fixed $\mathrm{Ca} / \mathrm{P} 1.67$ and a starting $\mathrm{pH} 3$.

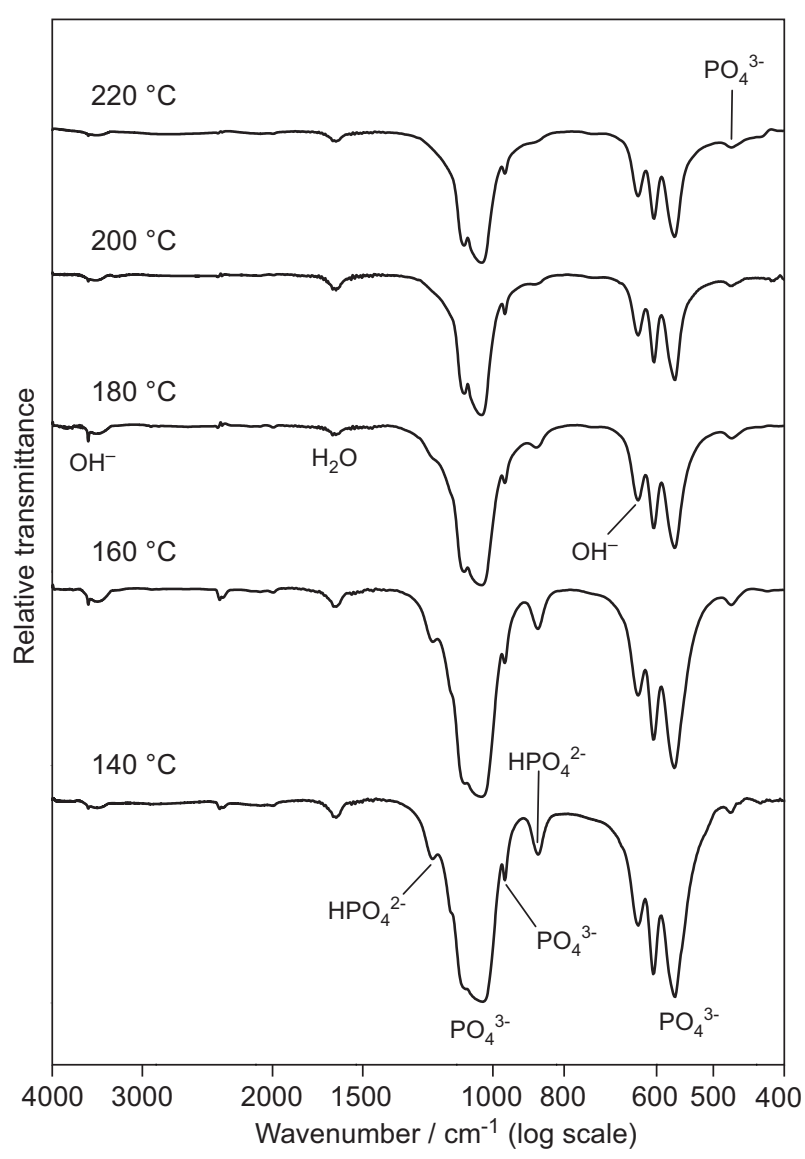

Figure 2. FTIR spectra of HA prepared at various temperatures using solutions with a fixed $\mathrm{Ca} / \mathrm{P} 1.67$ and a starting $\mathrm{pH} 3$.

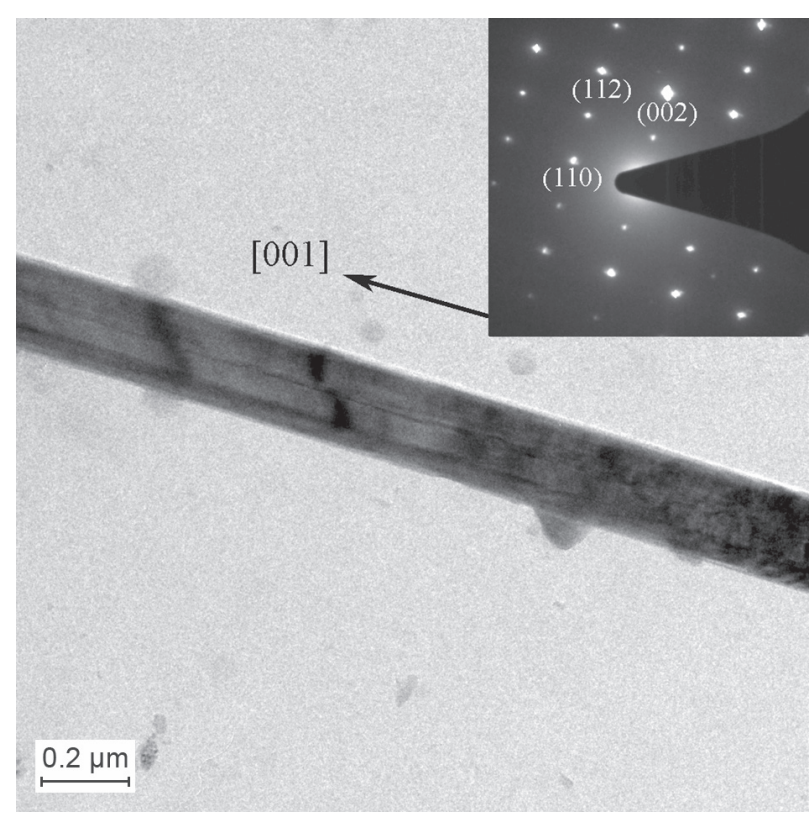

a) TEM

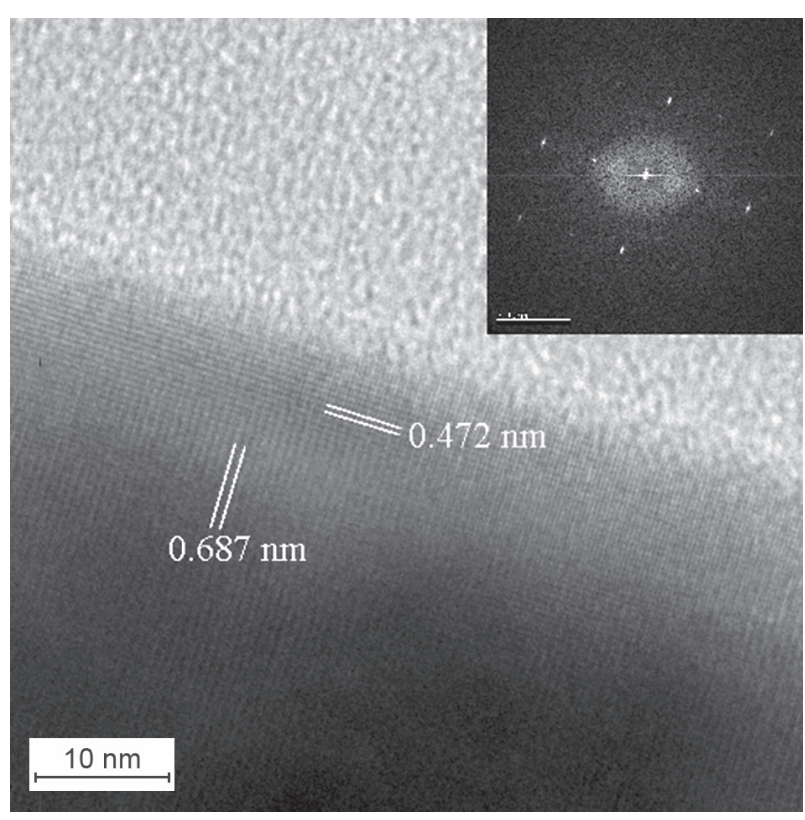

b) HRTEM

Figure 3. TEM images of HA whiskers prepared at $140^{\circ} \mathrm{C}$ using a solution with a $\mathrm{Ca} / \mathrm{P}$ ratio of 1.67 and $\mathrm{pH}$ 3: a) TEM, low magnification and SAED pattern (insert), and b) HRTEM image and Fourier transform pattern (inset). 
ratios, $\mathrm{I}_{(300)} / \mathrm{I}_{(002)}$ and $\mathrm{I}_{(300)} / \mathrm{I}_{(210)}$, varied from 43.5 to 55.6 and from 4.7 to 5.5 , respectively, and the $\mathrm{Ca} / \mathrm{P}$ ratio of the products ranged from 1.61 to 1.62 . These slight differences indicated that the synthesis temperature did not affect the crystal growth habit along the c-axis of HA crystals and the crystallographic characteristics. Further increase in temperature over $180^{\circ} \mathrm{C}$ did not show any obvious effect on the constitution or crystallinity of whiskers. However, for the samples prepared at $140^{\circ} \mathrm{C}$, the intensity ratios for both $\mathrm{I}_{(300)} / \mathrm{I}_{(002)}$ and $\mathrm{I}_{(300)} / \mathrm{I}_{(210)}$ were higher than at other temperatures, and the product formed at such low temperature had slightly higher Cadeficiency, with a $\mathrm{Ca} / \mathrm{P}$ ratio of 1.59 .

All the above findings could be also confirmed by the FTIR and TEM analysis. The characteristic bands at 1092, 1034, 602 and $564 \mathrm{~cm}^{-1}$ for phosphate group, and for hydroxyl at 3570 and $633 \mathrm{~cm}^{-1}$, were similar in each [29]. However, the absorption band at $871 \mathrm{~cm}^{-1}$, attributed to the symmetrical stretching vibration of $\mathrm{HPO}_{4}{ }^{2-}$ group, was obviously visible at low temperature, and their intensity was gradually decreased with increasing the temperature. The bending mode of $\mathrm{HPO}_{4}{ }^{2-}$ group at $1208 \mathrm{~cm}^{-1}$ only appeared in the spectra for specimens prepared at $140-160^{\circ} \mathrm{C}$ [29-31]. Although the products obtained at low temperature had high Ca-deficiency, the preferred growth orientation along the $c$-axis did not show any change (Figure 3 ). Strong reflection spots were identified as (002), (110) and (112) in the SAED pattern, and the whiskers had high purity and crystallinity [12] The longitudinal direction of the whiskers was parallel to the [001] direction. The calculated $d$-spacings for the (002), (110) and (112) lattice planes gave $3.426 \AA, 4.721$ $\AA$ and $2.774 \AA$, respectively; and the interfacial angles of $\alpha_{(110),(002)}$ and $\alpha_{(112),(002)}$ ranged $89.94^{\circ}$ and $36.27^{\circ}$. They matched well those calculated from the reference (JCPDF 9-432), which suggested that the prepared whiskers had the same crystallographic characteristics as normal HA crystals, despite the strongest XRD peak intensity appeared for the (300) lattice plane, rather than (211) as is usual for HA. Moreover, the HRTEM image showed a clear atomic arrangement and two lattice periodicities, the $d$-spacings for the (001) and (110) lattice planes gave $0.687 \mathrm{~nm}$ and $0.472 \mathrm{~nm}$, respectively, being coincident with the XRD analysis results.

\section{Effect of initial $\mathrm{pH}$}

The variation of length and width of the products prepared at various temperatures and initial $\mathrm{pHs}$ is shown in Figure 4. The length increased initially with the temperature, and then decreased for temperatures $>180^{\circ} \mathrm{C}$; the whiskers prepared at $\mathrm{pH} 3$ showed a high mean value in length. For whisker width, it increased with both the initial $\mathrm{pH}$ and the temperatures for samples prepared at the pHs 2 and 3. Long and uniform whiskers with high aspect ratio were obtained at $160-200^{\circ} \mathrm{C}$ and $\mathrm{pH} 3$ or at $180^{\circ} \mathrm{C}$ and $\mathrm{pH} 2$ (Figure 5), giving a mean length of $94-116 \mu \mathrm{m}$ and an aspect ratio of $89-103$. However, for the $\mathrm{pH} 4$, quick growth in width was clear when the temperature was at $180^{\circ} \mathrm{C}$, and the both the length and width decreased with further increase in temperatures, lath- or branch-like HA was often found to accompany the whiskers, being independent of the synthesis temperatures. In addition, when the preparation was conducted at $140^{\circ} \mathrm{C}$, a few irregular particles or rodor lath-like HA were found to appear in the products; at $220^{\circ} \mathrm{C}$, some aggregations composed of small needlelike particles or irregular plate-like particles were found in the products.

\section{DISCUSSION}

The effect of temperature on nucleation and crystal growth could be expressed through two aspects. The rate of nucleation and crystal growth benefits from increase in synthesis temperature: higher temperature, greater driving force. On the other hand, the rate of hydrolysis of AA is increased at a high temperature, which in turn made the solution $\mathrm{pH}$ increase more quickly. Here, these two changes led to a high supersaturation in a short period at high temperature, and more nuclei were formed initially. More $[\mathrm{Ca}],\left[\mathrm{PO}_{4}\right]$ and $[\mathrm{OH}]$ would be needed to satisfy the growth of large numbers of nuclei. A conflict occurred between the formation rate of nuclei and their growth; the crystal growth was limited by the concentration of each nutrient component. The supply of $\mathrm{Ca}$ and $\mathrm{PO}_{4}$ and $\mathrm{OH}$ became the rate-determining factor for crystal growth. As shown in Table 1, the final $\mathrm{pH}$ of synthesis solution increased firstly with the temperature and then decreased when the temperature was over $180^{\circ} \mathrm{C}$, being regardless of the starting $\mathrm{Ca} / \mathrm{P}$ ratio and initial $\mathrm{pH}$. Accompanying the decrease of the final $\mathrm{pH}$, the length of the whiskers also decreased (Figure 4), which was supposed to be caused by more nuclei formed in the solution and shortage in $\mathrm{OH}$ ions supply at high temperature. At low temperature, the crystals grew in a relatively-low $\mathrm{pH}$ due to slow hydrolysis rate of additive. The supply of each nutrient component could meet well the crystal growth, the length increasing with the temperature. However, the morphology of products was easily affected by the solution $\mathrm{pH}$, and a few irregular particles accompanied the whiskers for the preparation at $140^{\circ} \mathrm{C}$. Meanwhile, high $\mathrm{H}^{+}$activity could be the driving force for introducing hydrogen ions into the Casites of HA crystals, resulting in the formation of Cadeficient HA [32]. Therefore, the whiskers obtained at low temperature showed appreciable $\mathrm{HPO}_{4}{ }^{2-}$ bands in the FTIR spectra.

On the other hand, hydrothermal homogeneous precipitation of HA whiskers here is realized by the control of the solution $\mathrm{pH}$ value. The rate of nucleation and growth of crystals intimately depend on the degree of supersaturation, which directly relates with the $[\mathrm{Ca}]$ 
and $\left[\mathrm{PO}_{4}\right]$ in the starting solution and the hydrolysis rate of AA. Since the total amount of $\mathrm{Ca}$ and $\mathrm{PO}_{4}$ and the AA concentration were fixed throughout the whole experiments, the change of the starting $\mathrm{pH}$ gave rise to the variation of the degree of supersaturation, eventually affecting the nucleation and growth of HA crystals.

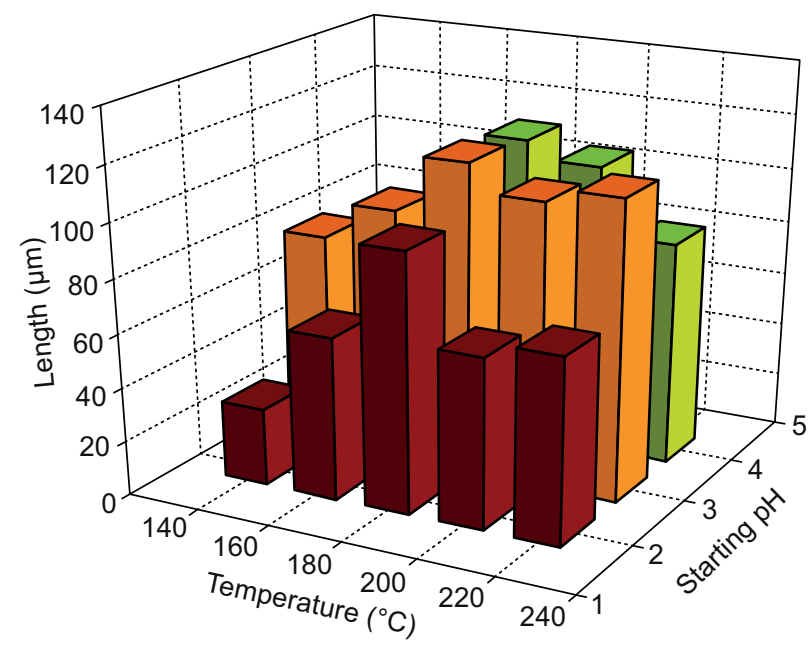

a)
For solutions with a given starting $\mathrm{Ca} / \mathrm{P}$, higher initial $\mathrm{pH}$ provided a basic reference for quickly obtaining supersaturation for the formation of HA nuclei. Higher initial $\mathrm{pH}$, more nuclei in the solution. Thus, the length varied with the initial $\mathrm{pH}$ at the examined temperatures, giving a high value at $\mathrm{pH} 3$ (Figure 4). In the case of

Figure 4. Variation of length and width of HA prepared at 140, 160, 200 and $220^{\circ} \mathrm{C}$ under various starting pHs.

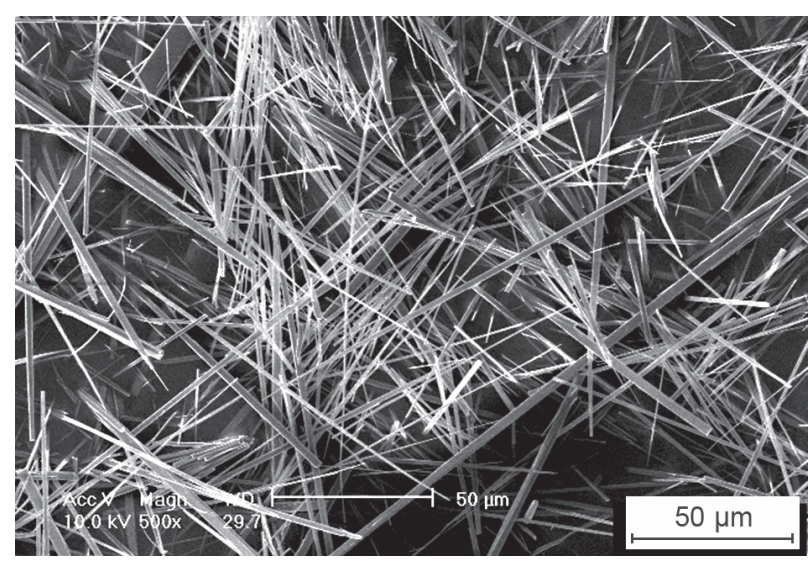

a) $\mathrm{pH} 3$ and $200^{\circ} \mathrm{C}$

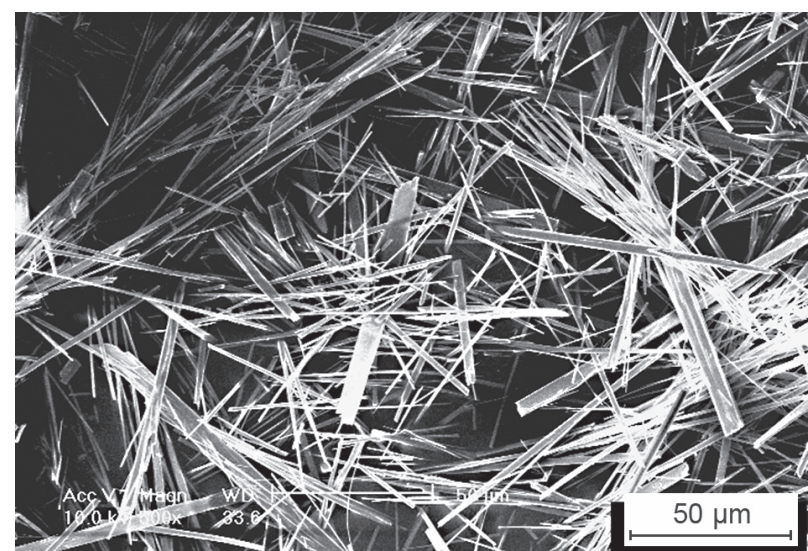

c) $\mathrm{pH} 4$ and $140^{\circ} \mathrm{C}$

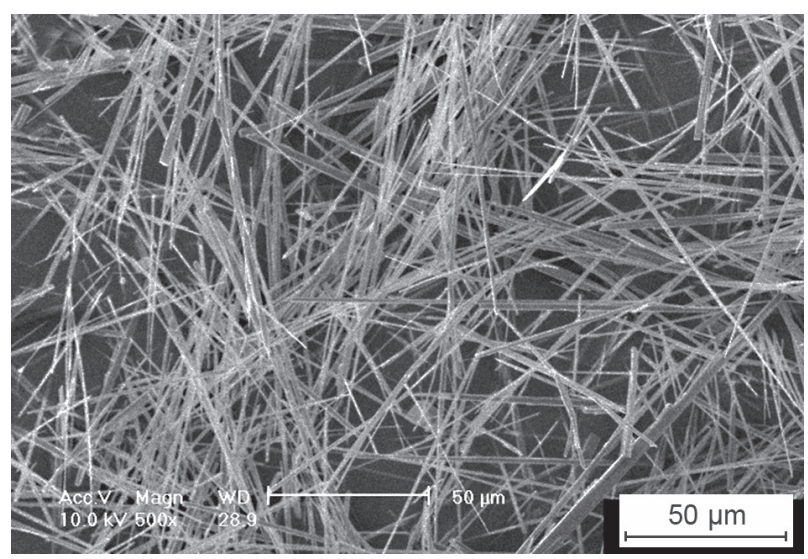

b) $\mathrm{pH} 2$ and $180^{\circ} \mathrm{C}$

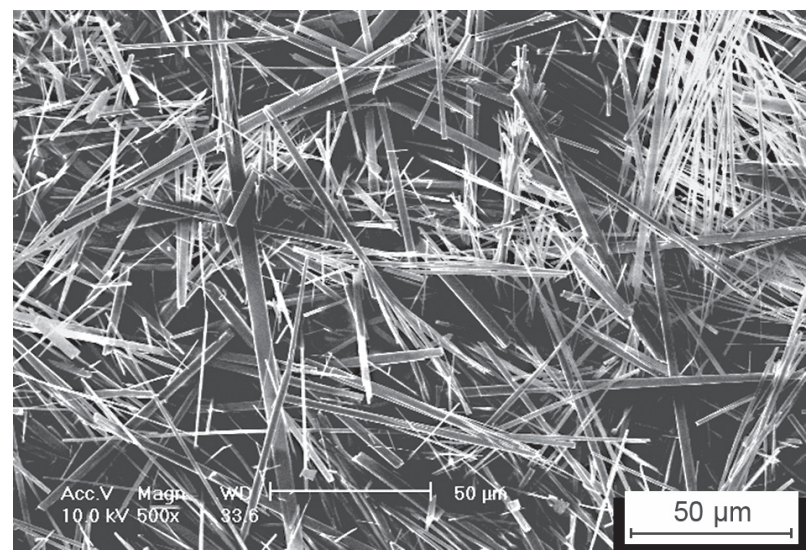

d) $\mathrm{pH} 4$ and $220^{\circ} \mathrm{C}$

Figure 5. SEM images of HA prepared using various starting $\mathrm{pHs}$ and temperatures at $\mathrm{Ca} / \mathrm{P}$ of 1.67 : a) $\mathrm{pH} 3$ and $\left.200^{\circ} \mathrm{C}, \mathrm{b}\right) \mathrm{pH} 2$ and $\left.180^{\circ} \mathrm{C}, \mathrm{c}\right) \mathrm{pH} 4$ and $\left.140^{\circ} \mathrm{C}, \mathrm{d}\right) \mathrm{pH} 4$ and $220^{\circ} \mathrm{C}$. 
the initial $\mathrm{pH}$ of 4 , since the competition with hydrogen ions for adsorption of $\mathrm{Ca}$ on $\{100\}$ faces became less intense due to the electrostatic attraction by $\mathrm{PO}_{4}$, the incorporation of more $\mathrm{Ca}$ on $\{100\}$ faces would accelerate the growth along the a-axis of the crystal. Thus, lath- or branch-like HA often appeared in the whiskers, being independent of the synthesis temperatures, which was coincident with our previous research [27].

\section{Summary}

Pure Ca-deficient HA whiskers were prepared at temperatures from 140 to $220^{\circ} \mathrm{C}$. The temperature studied here did not affect the constitution and crystallinity of the products as well as the crystal growth habit along the c-axis. However, the $\mathrm{Ca} / \mathrm{P}$ ratio of the products increased with the temperature, and the whiskers obtained at low temperature had high calcium deficiency. Whisker morphology greatly depended on the synthesis temperature and was correlated with the starting $\mathrm{pH}$ of the synthesis solution. Higher initials $\mathrm{pH}$ only provided a basic reference for quickly obtaining supersaturation for the formation of HA nuclei. Lath- or branch-like HA often appeared in the whiskers at high $\mathrm{pH}$, being independent of the synthesis temperatures. Neither high nor low temperatures were beneficial to the preparation of long HA with high aspect ratio. $180-200^{\circ} \mathrm{C}$ seemed to be an appropriate synthesis temperature to prepare long HA whiskers using a solution with $\mathrm{Ca} / \mathrm{P} 1.67$ under a starting $\mathrm{pH} 3$.

\section{Acknowledgements}

This work was supported by National Natural Science Foundation of China (No.51372182), and done in partial fulfillment of the requirements of the degree of Ph.D. for Hongquan Zhang at The University of Hong Kong.

\section{REFERENCES}

1. Wang M. (2004): Bioactive materials and processing, in Biomaterials and tissue engineering, Shi D., Editor. 2004, Springer: Berlin.

2. Kasuga T., Ota Y., Nogami M. Abe, Y. (2001): Preparation and mechanical properties of polylactic acid composites containing hydroxyapatite fibers. Biomaterials, 22(1), 19-23. doi: 10.1016/S0142-9612(00)00091-0

3. Suchanek W., Yashima M., Kakihan M.,Yoshimura M. (1997): Hydroxyapatite/hydroxyapatite-whiskers composites without sintering additives: Mechanical properties and microstructural evolution. Journal of the American Ceramic Society, 80(11): p. 2805-2813. doi: 10.1111/j.11512916.1997.tb03197.x

4. Xu H.H.K., Quinn J.B., DT Smith D.T., Giuseppetti A.A., Eichmiller F.C., (2003): Effects of different whiskers on the reinforcement of dental resin composites. Dental Materials, 19(5), 359-367. doi:10.1016/S0109-5641(02)00078-7
5. Dorner-Reisel A., Muller E., Tomandl G. (2004): Short fiber reinforced hydroxyapatite-based bioceramics. Advanced Engineering Materials, 2004. 6(7), 572-577. doi: 10.1002/ adem. 200400401

6. Castro A.G.B., Polini A., Azami Z., Leeuwenburgh S.C.G., Jansen J.A., Yang F., van den Beucken J. J. J. P. (2017): Incorporation of PLLA micro-fillers for mechanical reinforcement of calcium-phosphate cement. Journal of the Mechanical Behavior of Biomedical Materials, 71, 286294. doi:10.1016/j.jmbbm.2017.03.027

7. Pangon A., Saesoo S., Saengkri N., Ruktanonchai U., Intasanta V. (2016): Hydroxyapatite-hybridized chitosan/ chitin whisker bionanocomposite fibers for bone tissue engineering applications. Carbohydrate Polymers, 144, 419-427. doi:10.1016/j.carbpol.2016.02.053

8. Charvet J.L., Cordes J.A., Alexander H. (2000): Mechanical and fracture behavior of a fiber-reinforced bioabsorbable material for orthopaedic applications. Journal of Materials Science: Materials in Medicine, 11(2), 101-109. doi: 10.1023/A:1008945017668

9. Tanahashi M., Kamiya K., Suzuki T., Nasu H. (1992): Fibrous hydroxyapatite grown in the gel system - Effects of $\mathrm{pH}$ of the solution on the growth-rate and morphology. Journal of Materials Science: Materials in Medicine, 3(1), 48-53. doi:10.1007/BF00702944

10. Ota Y., Iwashita T., Kasuga T., Abe Y. (1998): Novel preparation method of hydroxyapatite fibers. Journal of the American Ceramic Society, 81(6), 1665-1668. doi: 10.1111/ j.1151-2916.1998.tb02529.x

11. Zhang H.Q., Wang Y.F., Yan Y.H., Li S.P. (2003): Precipitation of biocompatible hydroxyapatite whiskers from moderately acid solution. Ceramics International, 29(4), 413-418. doi: 10.1016/S0272-8842(02)00153-0

12. Jokić B., Mitrić M., Radmilović V., Drmanić S., Petrović R., Janaćković D. (2011): Synthesis and characterization of monetite and hydroxyapatite whiskers obtained by a hydrothermal method. Ceramics International, 37(1), 167-173. doi: 10.1016/j.ceramint.2010.08.032

13. Yoon S.Y., Parka Y.M., Parkb S.S., Stevensc R., Parka H.C. (2005): Synthesis of hydroxyapatite whiskers by hydrolysis of a-tricalcium phosphate using microwave heating. Materials Chemistry and Physics, 91(1), 48-53. doi: 10.1016/j.matchemphys.2004.10.049

14. Yoshimura M., Suda H. (1994): Hydrothermal processing of hydroxyapatite: Past, present, and future, in Hydroxyapatite and Related Materials, Brown P.W. and Constantz B., Editors. 1994, CRC Press: Boca Raton.

15. Suchanek W., Suda H., Yashima M., Kakihana M., Yoshimura M. (1995): Biocompatible whiskers with controlled morphology and stoichiometry. Journal of Materials Research, 1995. 10(3), 521-529. doi: 10.1557/JMR.1995. 0521

16. Tas A.C. (2001): Molten salt synthesis of calcium hydroxyapatite whiskers. Journal of the American Ceramic Society, 84(2), 295-300. doi: 10.1111/j.1151-2916.2001.tb00653.x

17. Qi M.L., He K., Huang Z.N., Shahbazian-Yassar R., Xiao G.Y., Lu Y.P., Shokuhfar T. (2017): Hydroxyapatite Fibers: A Review of Synthesis Methods. Journal of the Minerals, Metals \& Materials Society, 69, 1-7. doi: 10.1007/s1183

18. Toyama T., Oshima A., Yasue T. (2001): Hydrothermal synthesis of hydroxyapatite whisker from amorphous calcium phosphate and the effect of carboxylic acid. Journal of the 
Ceramic Society of Japan, 109(3), 232-237. doi:10.2109/ jcersj.109.1267_232

19. Yasukawa A., Kamiuchi K., Yokoyama T., Ishikawa T. (2002): Preparation of lead-calcium hydroxyapatite solid solutions by a wet method using acetamide. Journal of Solid State Chemistry, 163(1), 27-32. doi: 10.1006/jssc.2001. 9348

20. Kandori K., Horigami N., Yasukawa A., Ishikawa T. (1997): Texture and formation mechanism of fibrous calcium hydroxyapatite particles prepared by decomposition of calcium-EDTA chelates. Journal of the American Ceramic Society, 80(5), 1157-1164. doi: 10.1111/j.1151-2916.1997. tb02958.x

21. Iizuka T., Nozuma A. (1999): Effects of the buffer solutions on the growth of hydroxyapatite whiskers. Journal of the Ceramic Society of Japan, 107(5), 442-448. doi: 10.2109/ jcersj.107.442

22. Aizawa M., Ueno H., Itatani K., Okada I. (2006): Syntheses of calcium-deficient apatite fibres by a homogeneous precipitation method and their characterizations. Journal of the European Ceramic Society, 26(4-5), 501-507. doi: 10.1016/j.jeurceramsoc.2005.07.007

23. Li C., Liu S., Li G., Bai J., Wang W., Du Q. (2011): Hydrothermal synthesis of large-sized hydroxyapatite whiskers regulated by glutamic acid in solutions with low supersaturation of precipitation. Advanced Powder Technology, 22(4), 537-543. doi: 10.1016/j.apt.2010.07.013

24. Fujishiro Y., Yabuki H., Kawamura K., Sato T., Okuwaki A. (1993): Preparation of needle-like hydroxyapatite by homogeneous precipitation under hydrothermal conditions. Journal of Chemical Technology and Biotechnology, 57(4), 349-353. doi: 10.1002/jctb.280570409
25. Roeder R.K., Converse G.L., Leng H., Yue, W. (2006): Kinetic effects on hydroxyapatite whiskers synthesized by the chelate decomposition method. Journal of the American Ceramic Society, 89(7), 2096-2104. doi: 10.1111/j.15512916.2006.01067.x

26. Zhang H.Q., Darvell B.W. (2010): Constitution and morphology of hydroxyapatite whiskers prepared using amine additives. Journal of the European Ceramic Society, 30(10), 2041-2048. doi: 10.1016/j.jeurceramsoc.2010.04.013

27. Zhang H.Q., Darvell B.W. (2010): Synthesis and characterization of hydroxyapatite whiskers by hydrothermal homogeneous precipitation using acetamide. Acta Biomaterialia, 6(8), 3216-3222. doi:10.1016/j.actbio.2010.02.011

28. Nilen R.W.N., Richter P.W. (2008): The thermal stability of hydroxyapatite in biphasic calcium phosphate ceramics. Journal of Materials Science-Materials in Medicine, 19(4), 1693-1702. doi: 10.1007/s10856-007-3252-x

29. Koutsopoulos S. (2002): Synthesis and characterization of hydroxyapatite crystals: A review study on the analytical methods. Journal of Biomedical Materials Research, 62(4), 600-612. doi: 10.1002/jbm.10280

30. LeGeros R.Z. (1991): Calcium Phosphates in Oral Biology and Medicine, in Monographs in Oral Sciences, H. Myers, Editor. 1991, S. Karger,: Basel.

31. Park H.C., Baek D.J., Park Y.M., Yoon S.Y., Stevens, R. (2004): Thermal stability of hydroxyapatite whiskers derived from the hydrolysis of $\alpha$-TCP. Journal of Materials Science, 39(7), 2531-2534. doi: 10.1023/B:JMSC.0000020021. $82216.6 \mathrm{~b}$

32. Ito A., Nakamura S., Aoki H., Akao M., Teraoka K., Tsutsumi S., Onuma K., Tateishi T. (1996): Hydrothermal growth of carbonate-containing hydroxyapatite single crystals. Journal of Crystal Growth, 163(3), 311-317. doi: 10. 1016/0022-0248(95)00955-8 